\title{
Stormwater Runoff Treatment Using Moringa Oleifera Seed Extract as a Natural Coagulant
}

\author{
Bobor, L. O. ${ }^{1, *}$ and Aghedo, A. G. ${ }^{2}$ \\ ${ }^{1,2}$ Department of Civil Engineering, Faculty of Engineering, University of Benin, Benin City, Edo State, Nigeria \\ Corresponding Author: *lulu.akhigbe@ uniben.edu
}

https://doi.org/10.36263/nijest.2020.01.0192

\begin{abstract}
Uncontrolled stormwater runoff poses a serious threat to aquatic ecosystems due the presence of harmful pollutants. Effective treatment is important prior to discharge. This study investigated the performance of Moringa oleifera seed extract as a coagulant for the reduction of turbidity, chemical oxygen demand (COD) and total suspended solids (TSS) in stormwater runoff. Stormwater samples were treated with Moringa oleifera seed extract solution at varied coagulant doses (0.5-10\%), $p H$ (3-10) and settling durations (20-60 minutes). The samples were analyzed before and after treatment to determine the coagulation efficiencies. There were improvements in stormwater quality, with up to $88 \%, 70 \%$ and $89 \%$ reduction in turbidity, COD and TSS levels achieved. Removal efficiencies increased with increase in coagulant dose and settling time. The results of the study indicate that Moringa oleifera can be used in the treatment of stormwater runoff for safe discharge into the aquatic environment.
\end{abstract}

Keywords: Stormwater runoff, Moringa oleifera, Coagulation, Turbidity, TSS, COD

\subsection{Introduction}

Stormwater runoff contains several pollutants, which are detrimental to aquatic systems and consequently humans and animals. Hence, the reduction of pollutant loads before discharge is a critical component of storm water management in addition to flood control. Methods that have been employed in treatment include the use of detention ponds, infiltration basins, wetlands, etc. (Price and Yonge, 1995; Nystrom, 2019). Detention ponds provide some level of pollutant removal through sedimentation, though smaller particle fractions are not efficiently removed. Coagulation and flocculation is effective in the removal of these smaller particle fractions (colloidal particles) (Price and Yonge, 1995; Nystrom, 2019). Coagulation is the destabilization of the insoluble dispersed negatively charged particles present in a suspension by the addition of a coagulant while flocculation is the process by which the destabilized particles come in contact to form larger flocs (Bratby, 2016). Chemical coagulants such as aluminum sulphate (alum) and ferric sulphate have been used in stormwater treatment with significant reductions in turbidity, TSS, COD, total phosphorus (Heinzmann, 1994; Price and Yonge, 1995; Harper et al., 1999; Harper, 2007; Kang et al., 2007; Nystrom et al., 2019). In practice, these coagulants have been used in stormwater runoff treatment via automatic chemical injection systems into the receiving water bodies ( Harper and Herr, 2000) or diversion into settling basins for coagulant dosing, mixing and settling before discharge (Brown and Caldwell, 2016). Disadvantages associated with chemical coagulation include high costs, large volumes of sludge, changes in $\mathrm{pH}$ and toxicity to aquatic organisms at certain doses (Lopus et al., 2009; Bakare, 2016; Dehghani and Alizadeh, 2016; Shan et al., 2017). Natural coagulants such as Moringa oleifera are safe low-cost alternatives.

Moringa oleifera is a widely cultivated tropical tree with diverse nutritional and water treatment applications. It is biodegradable, has a natural buffering capacity and lower sludge volume with no known toxic effects (Lea, 2010; Bakare, 2016; Dehghani and Alizadeh, 2016; Shan et al., 2017; Diaz et al., 2018). The Moringa oleifera seed consists of $34.1 \%$ protein, $15 \%$ carbohydrate and $15.5 \%$ lipids (Olayemi and Alabi, 1994; Lea, 2010). The active agents present in the seeds have been identified as proteins with cationic peptides consisting of positively charged amino acids and 
glutamine residues with molecular weights ranging from 6-16kDa (Ndabigengesere et al. 1995; Idris et al., 2016). The use of Moringa oleifera seeds and/or leaves as a natural coagulant for turbidity removal from water has been investigated (Ali et al., 2009; Lea, 2010; Bakare, 2016; Dehghani and Alizadeh, 2016; Adeniran et al., 2017; Shan et al., 2017). These studies have focused on applications in water and wastewater treatment; however the present study focuses on the treatment of stormwater runoff using the natural coagulant.

The aim of this study is to investigate the performance of Moringa oleifera seed extract as a natural coagulant for stormwater treatment. The impact of coagulant dose, $\mathrm{pH}$ and settling time on the removal of turbidity, chemical oxygen demand (COD) and total suspended solids (TSS) will be evaluated.

\subsection{Methodology}

\subsection{Preparation of Moringa oleifera seed extract.}

Moringa oleifera seeds were removed from mature pods, de-husked and dried for one day. The dry seeds were pulverized to a fine powder using a domestic blender. The powder was sieved through a $0.8 \mathrm{~mm}$ sieve, dried at $40{ }^{\circ} \mathrm{C}$ for $10 \mathrm{~min}$ to reduce the moisture content and packed in an airtight container on cooling. A $2 \%$ suspension of Moringa oleifera seed powder in distilled water was agitated for 5 mins and left to settle for 10 minutes to obtain the seed extract (Lea, 2010).

\subsection{Stormwater sampling and analysis}

Stormwater runoff was obtained from Isihor, Benin City. The map of the study area is shown in Figure 1. Grab samples were taken from an unlined ditch adjacent to the Benin-Lagos highway after a storm event in October, 2019. This was one of the improvised flood control measures near a bad section of the road at the time of this study. The samples were collected using clean plastic bottles and taken to the laboratory for physicochemical analysis in accordance with standard methods for the examination of water and wastewater (APHA, 2005).

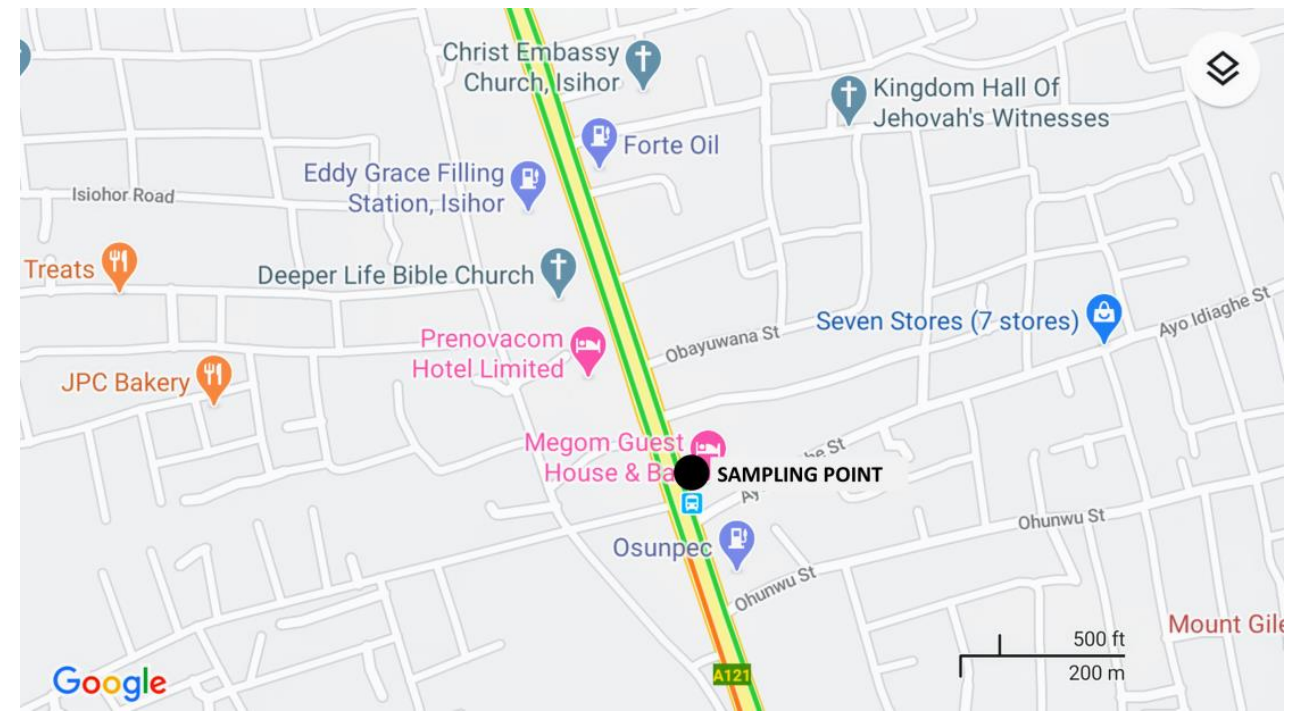

Figure 1: Map of the study area

(Source: Google Maps)

The $\mathrm{pH}$ was determined using a $\mathrm{pH}$ meter calibrated with standard solutions ( $\mathrm{pH} 4.0,6.8$ and 9.2) before measurements. Turbidity was measured using the Hach turbidimeter. The chemical oxygen demand (COD) was determined using a Hach UV spectrophotometer. Standard gravimetric analysis was used to determine the TSS and TDS based on weight difference. The TSS was determined by passing a known amount of water through a pre-weighed glass fibre filter paper which was dried at $105{ }^{\circ} \mathrm{C}$ and then weighed. The increase in the weight of the filter per volume of sample filtered was determined. The TDS was measured by passing a known amount of water through a glass fibre filter paper. The filtrate was placed in a pre-weighed dish, dried at $105^{\circ} \mathrm{C}$ and the weight of dry residue 
per sample volume was determined (APHA, 2005). The concentration of metals ( $\mathrm{Pb}, \mathrm{Cd}$ and $\mathrm{Zn}$ ) was determined using a Unicam 929 atomic absorption spectrometer (AAS).

\subsection{Jar tests}

Jar tests were conducted using a conventional jar test apparatus consisting of four $1000 \mathrm{~mL}$ beakers with rotating paddles. The different coagulant concentrations were added to water samples, which were rapidly mixed at $125 \mathrm{rpm}$ for 5 minutes followed by 30 minutes of slow mixing at $50 \mathrm{rpm}$. The samples were left undisturbed for the specified settling time before collection for physicochemical analysis. The effects of coagulant dose (0.5-10\% suspensions), $\mathrm{pH}$ (3-10) and settling time (20, 40 and 60 minutes) on the removal of turbidity, TSS and COD were investigated.

\subsection{Results and Discussion}

\subsection{Stormwater quality parameters}

The stormwater runoff was characterized before treatment with results shown in Table 1. These values were compared with the physicochemical ambient water quality criteria for surface water as stipulated in the National Environmental (Surface and Groundwater Quality Control) Regulations (Federal Republic of Nigeria Official Gazette, 2011) and the United States Environmental Protection Agency (US EPA) multi-sector permit for stormwater discharge (USEPA, 2008).

Table 1: Comparison of stormwater quality parameters obtained from grab sampling with standards.

\begin{tabular}{lccc}
\hline Parameter & Stormwater Runoff & *NIG (2011) & USEPA (2008) \\
\hline Turbidity (NTU) & 358.41 & & 50 \\
Chemical Oxygen Demand (COD) (mg/l) & 162 & 30 & 100 \\
Total Suspended Solids (TSS) (mg/l) & 750 & & 120 \\
Total Dissolved Solids (TDS) (mg/l) & 75 & $6.0-9.0$ \\
$\mathrm{pH}$ & 8.7 & $6.5-8.5$ & 0.1 \\
Lead (mg/l) & 0.21 & 0.2 & \\
Zinc (mg/l) & 1.93 & 0.01 & \\
Cadmium (mg/l) & 0.06 & \\
Note: these values from grab sampling are a snapshot of the stormwater quality at a specific time and location and \\
unsuitable for regulatory purposes \\
*Federal Republic of Nigeria Official Gazette, 2011
\end{tabular}

The turbidity and TSS exceeded the US EPA guideline values for stormwater discharge, while the COD, lead, cadmium and zinc levels did not comply with the (Nigerian) physicochemical ambient water quality criteria for surface water. Stormwater pollution may be attributed to the prevalent anthropogenic activities and land-use in the study area (Nystrom, 2019; Song et al., 2019). Atmospheric depositions from high vehicular traffic on the major highway and adjoining streets are conveyed in stormwater runoff. Furthermore pavement failure due to poor drainage has resulted in the release and conveyance of large amounts of debris in flood waters. The erosion of several unpaved roads in the area aggravated by storm events is a continuous source dust and sediments. Soil, dust and debris from construction and agricultural activities and indiscriminate solid waste disposal are also major sources of pollution. The presence of pollutants which are detrimental to receiving water bodies highlights the need for an integrated approach to water resources management which includes stormwater quality monitoring and treatment in addition to flood control.

Jar tests were conducted to evaluate the performance of Moringa oleifera seed extract and the effect of operating conditions on the coagulation process. The reduction in turbidity, TSS and COD levels as a function of coagulant dose, $\mathrm{pH}$ and settling time are shown in Table 2. These three parameters were selected for ease of measurement and because they were far above the guideline values/surface water quality criteria

\subsection{Effect of coagulant dose}

The effect of varying the coagulant dose on the removal of turbidity, COD and TSS is shown in Figure 2 and Table 2. There was a general decrease in contaminant levels (increased removal) as the 
coagulant dose was increased up to the maximum concentration of $10 \%$ used in this study. The turbidity of stormwater runoff decreased from $358.41 \mathrm{NTU}$ to $44.72 \mathrm{NTU}$ (87.52\% removal) at the maximum coagulant dose of $10 \%$. Similarly the COD decreased from $162 \mathrm{mg} / \mathrm{L}$ to $52 \mathrm{mg} / \mathrm{L}(67.90 \%)$ and TSS decreased from $750 \mathrm{mg} / \mathrm{L}$ to $80 \mathrm{mg} / \mathrm{L}$ ( $89.33 \%$ removal).

Similar trends have been reported with the use of Moringa oleifera seeds for the treatment of highly turbid river water (Bakare, 2016), oil-refining wastewater (Dehghani and Alizadeh, 2016). Adeniran et al. (2017) also reported in a study that there was a reduction in the levels of COD, TSS and turbidity present in domestic sewage as the applied coagulant (Moringa oleifera) dose increased. Moringa oleifera seeds contain natural soluble cationic polyelectrolytes, which were released into the extract. These polyelectrolytes are natural flocculating agents that bind colloids present in the stormwater, resulting in the formation of large flocs (Lea, 2010). The mechanisms involved in the coagulation process include neutralization of negatively charged colloidal particles (destabilization), flocculation, interparticle bridging and adsorption (Shin et al., 2008; Sotheeswaran et al., 2011; Dehghani and Alizadeh ,2016).

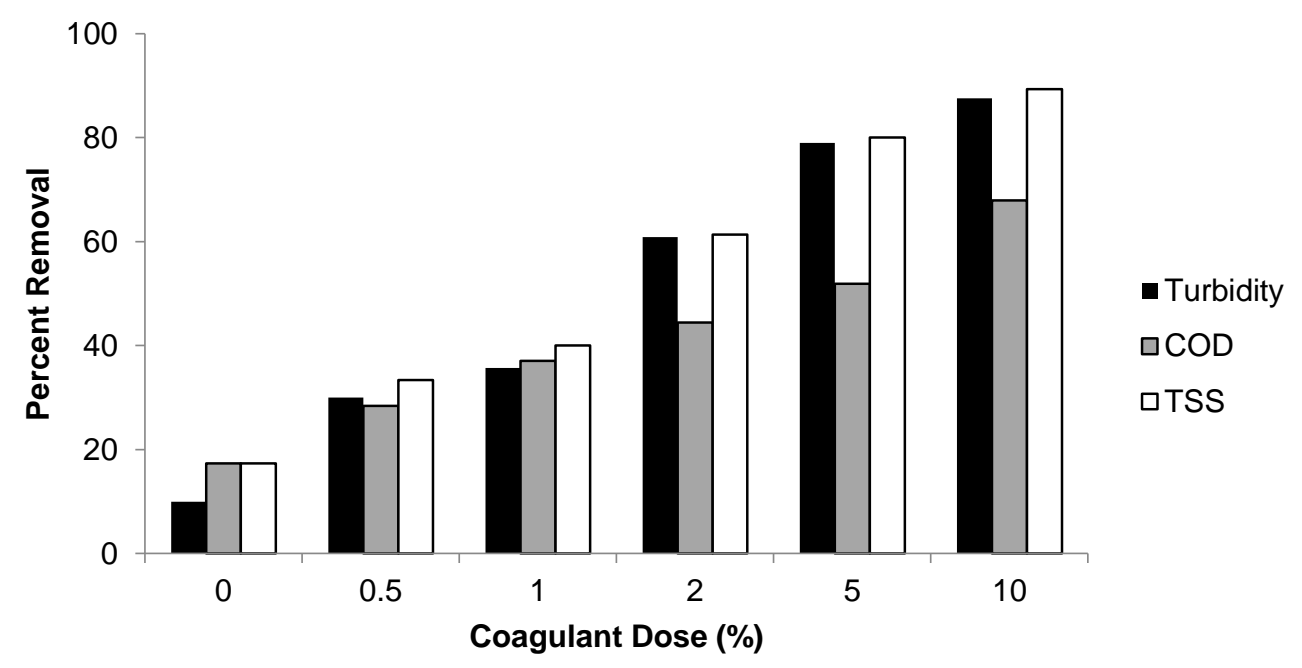

Figure 2: Effect of coagulant dose on the percent reduction in turbidity, COD and TSS

Table 2: Effect of Moringa oleifera on turbidity, TSS and COD levels in stormwater runoff

\begin{tabular}{ccccccc}
\hline & \multicolumn{2}{c}{ Turbidity (NTU) } & \multicolumn{2}{c}{ COD (mg/l) } & \multicolumn{2}{c}{ TSS (mg/l) } \\
\hline Coagulant Dose (\%) & Initial & Final & Initial & Final & Initial & Final \\
0.5 & 358.41 & 250.91 & 162 & 116 & 750 & 500 \\
1 & 358.41 & 230.48 & 162 & 102 & 750 & 450 \\
2 & 358.41 & 140.4 & 162 & 90 & 750 & 290 \\
5 & 358.41 & 75.47 & 162 & 78 & 750 & 150 \\
10 & 358.41 & 44.72 & 162 & 52 & 750 & 80 \\
\hline pH & & & & & & \\
3 & 358.41 & 40.85 & 162 & 48 & 750 & 60 \\
5 & 358.41 & 43 & 162 & 52 & 750 & 78 \\
7 & 358.41 & 53.32 & 162 & 62 & 750 & 92 \\
10 & 358.41 & 72.03 & 162 & 78 & 750 & 110 \\
\hline Settling Time (Mins) & & & & & & \\
0 & 358.41 & 154.8 & 162 & 96 & 750 & 340 \\
20 & 358.41 & 119.97 & 162 & 88 & 750 & 218 \\
40 & 358.41 & 79.12 & 162 & 82 & 750 & 142 \\
60 & 358.41 & 45.58 & 162 & 54 & 750 & 88 \\
\hline
\end{tabular}




\subsection{Effect of $p H$}

The effect of $\mathrm{pH}$ on the removal of turbidity, COD and TSS is shown in Figure 3 and Table 2. The coagulation efficiencies varied from $79-88 \%$ for turbidity, $51-70 \%$ for COD and $85-92 \%$ for TSS, with optimum coagulation observed at $\mathrm{pH} 3$. The results indicate a decrease in removal efficiencies with increase in $\mathrm{pH}$ levels (particularly at $\mathrm{pH}>7$ ). Similarly observations have been reported for $\mathrm{pH}$ values ranging from 6 to 9 . In a study investigating the influence of $\mathrm{pH}$ on the treatment of wastewater from oil refining using Moringa oleifera, It was observed that after an initial increase across $\mathrm{pH} 5$ to 6, the removal efficiencies of TSS, COD and turbidity decreased as the $\mathrm{pH}$ was increased from 6 to 9 (Dehghani and Alizadeh, 2016). However, the optimal $\mathrm{pH}$ range for coagulation depends on the specific pollutants present in the water and their interactions. Furthermore, it has been reported that the structure and surface charges of organic coagulants such as Moringa oleifera seeds tend to be altered by changes in $\mathrm{pH}$, thus influencing the coagulation process (Naceradska et al., 2019).

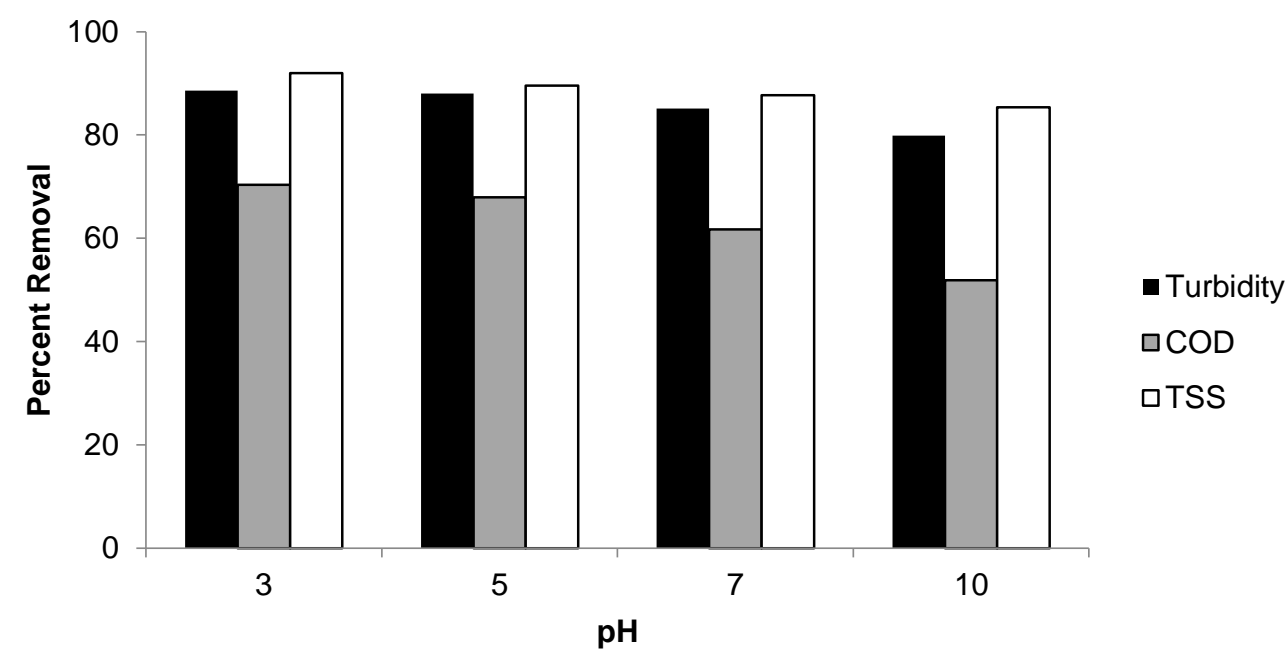

Figure 3: Effect of stormwater $\mathrm{pH}$ on the percent reduction in turbidity, COD and TSS

\subsection{Effect of settling time}

The impact of settling times (0-60 minutes) on the treatment process was evaluated with results showing a gradual increase in pollutant removal as the settling time increased as shown in Table 2. The removal efficiencies were $87.28,66.67$ and $88.27 \%$ for turbidity, COD and TSS respectively after 60 minutes of settling as shown in Figure 4. Similarly, it has been reported in the literature that turbidity removal from water increased with settling time (Kang and Trevino, 2017).

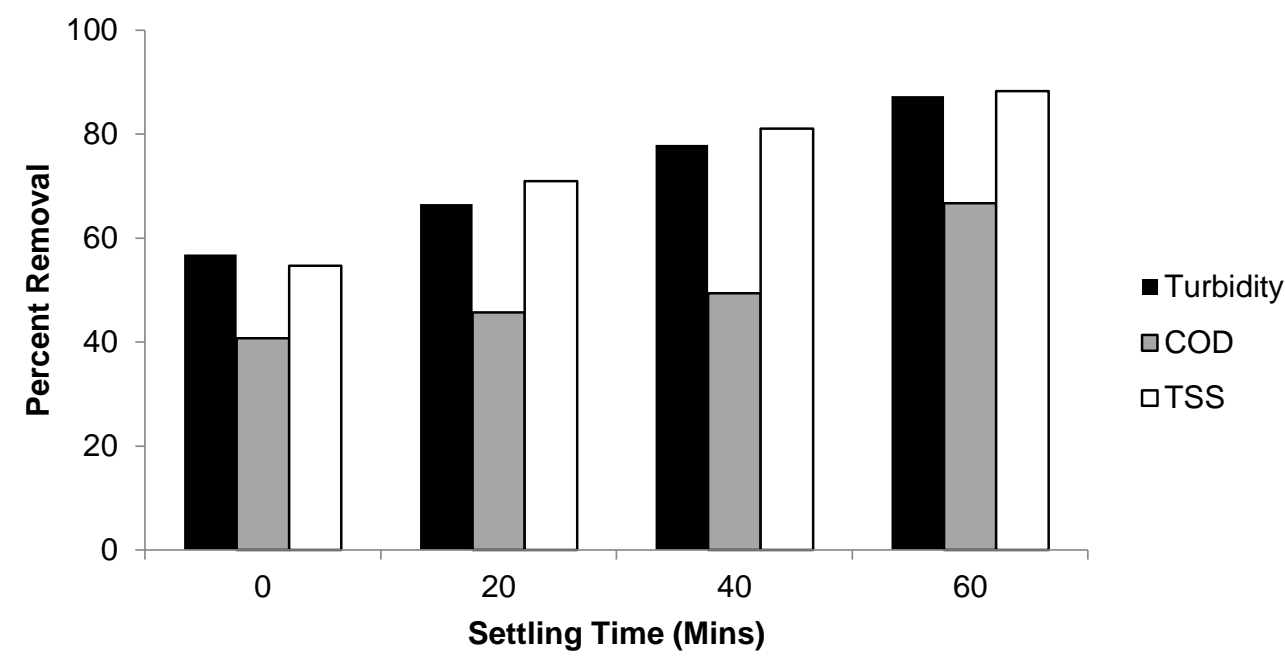

Figure 4: Effect of settling time on the percent reduction in turbidity, COD and TSS 
Overall removal efficiencies of up to 88,70 and $89 \%$ for turbidity, COD and TSS respectively were recorded. These findings are generally in agreement with studies on the use of Moringa oleifera in the treatment of different contaminated aqueous streams (Dehghani and Alizadeh, 2016; Adeniran et al., 2017; Shan et al., 2017). Moringa oleifera seed reduced turbidity in river water samples by $85-94 \%$ (Shan et al., 2017). The observed reduction in turbidity levels (up to 88\%) is comparable with the $90 \%$ reduction reported in a recent study involving the use of chemical coagulants for the treatment of stormwater runoff (Nystrom et al., 2019). These findings demonstrate the suitability of this coagulant as a cost-effective eco-friendly alternative for stormwater treatment.

\subsection{Conclusions}

The use of Moringa oleifera seed extract as a natural coagulant for stormwater runoff treatment was investigated in this study. Maximum coagulation efficiencies of 88,70 and $89 \%$ for turbidity, COD and TSS respectively were achieved. The results showed that coagulation efficiency was influenced by coagulant dose, $\mathrm{pH}$ and settling time. The maximum turbidity removal achieved was comparable with the performance of chemical coagulant used in stormwater treatment in a similar study. Moringa oleifera can be used as a cheaper and safer alternative to chemical coagulation for stormwater treatment, as part of an integrated stormwater management system.

\section{References}

Adeniran, K. A., Akpenpuun, T. D., Akinyemi, B. A. and Wasiu, R. A. (2017). Effectiveness of Moringa oleifera seed as a coagulant in domestic wastewater treatment. African Journal of Science, Technology, Innovation and Development, 9(3), pp. 323-328.

Ali, E. N., Muyibi, S. A., Salleh, H. M., Salleh, M. R. and Alam, M. Z. (2009). Moringa oleifera seeds as natural coagulant for water treatment. Thirtheeth International Water Technology Conference, IWTC 13, 2009, Hurghada, Egypt.

APHA (2005). Standard Methods for the Examination of Water and Wastewater. $21^{\text {st }}$ edition. American Public Health Association/American Water Works Association/Water Environment Federation, Washington DC.

Bakare, B. F. (2016). An investigation of Moringa oleifera seed extract as a natural coagulant in water treatment. Proceedings of the World Congress on Engineering and Computer Science (WCECS 2016), October 19-21, San Francisco, USA.

Bratby, J. (2016). Coagulation and flocculation in water and wastewater treatment. $3^{\text {rd }}$ edition, IWA publishing London.

Brown and Caldwell (2016). Phase I feasibility analysis: Use of coagulant for phosphorus treatment at Starkweather Creek, Madison WI. Prepared for City of Madison, WI

Dehghani, M. and Alizadeh, M. H. (2016). The effects of the natural coagulant Moringa oleifera and alum in wastewater treatment at the Bandar Abbas Oil Refinery. Environmental Health Engineering and Management Journal, 3(4), pp. 225-230

Diaz, J. J. F., BallutDajud, G. and Miranda, J. P. R. (2018). Influence of storage time of Moringa oleifera seed on the coagulant activity efficiency of raw water treatment. Indian Journal of Science and Technology, 11(9), pp. 1-4.

Federal Republic of Nigeria (2011). National Environmental (Surface and Groundwater Quality Control) Regulations. Federal Republic of Nigeria Official Gazette, Lagos. No. 49, Vol. 98, Supplement No. 22. pp. B693-727

Harper, H. H. (2007) Current research trends in alum treatment of stormwater runoff. Proceedings of the $3^{\text {rd }}$ biennial stormwater management research symposium, Orlando 
Harper, H. H. and Herr, J. L. (2000). Chemical coagulation of stormwater runoff: an economical alternative for reducing nonpoint source impacts. Proceedings of the Delaware urban erosion, sediment and stormwater conference. Newark Delaware, October 24-16, 2000

Harper, H. H., Herr, J. L. and Livingston, E. H. (1999). Alum treatment of stormwater runoff: an innovative BMP for urban runoff problems. National conference on retrofit opportunities for water resource protection in urban environments.

Heinzmann, B. (1994). Coagulation and flocculation of stormwater from a separate sewer system-a new possibility for enhanced treatment. Water Science and Technology, 29, pp. 267-278.

Idris, M. A., Jami, M. S., Hammed, A. M. and Jamal, P. (2016) Moringa oleifera seed extract: a review on its environmental applications. International Journal of Applied Environmental Sciences, 11(6), pp. 1469-1486.

Kang, J. and Trevino, J. (2017) Evaluating Moringa oleifera, papaya and pumpkin seed as a natural coagulant. International Journal of Life Sciences Research, 5(2), pp. 126 -131.

Kang, J. H., Li, Y., Lau, S. L., Kayhanian, M. and Stenstrom, M. K. (2007) Particle destabilization in highway runoff to optimize pollutant removal. Journal of environmental engineering, 133, pp. 426434 .

Lea, M. (2010) Bioremediation of turbid water using seed extract from the Moringa oleifera Lam. (Drumstick) Tree. Current Protocols in Microbiology, 16(1), pp. 1G.2.1-1G.2.8.

Lopus, S. E., Bachand, P. A. M., Heyvaert, A. C., Werner, I., Teh, S. J. and Reuter, J. E. (2009). Potential toxicity concerns from chemical coagulation treatment of stormwater in the Tahoe basin, California, USA. Ecotoxicology and Environmental Safety, 72(7), pp. 1933-1941.

Naceradska, J., Pivokonska, L. and Pivokonsky, M. (2019) On the importance of pH value in coagulation. Journal of Water Supply: Research and Technology-Aqua, 68(3), pp. 222-130.

Ndabigengesere, A., Narasiah, K. S. and Talbot, B. G. (1995). Active agents and mechanism of coagulation of turbid waters using Moringa oleifera. Water Research, 29(2), pp. 703-710.

Nystrom, F. (2019) Coagulation process characteristics and pollutant removal from urban runoff, Licentiate thesis, Lulea University of Technology, Lulea, Sweden.

Nystrom, F., Nordqvist, K., Herrmann, I., Hedstrom, A. and Viklander, M. (2019). Treatment of road runoff by coagulation/flocculation and sedimentation. Water Science and Technology, 79(3), pp. 518525 .

Olayemi, A. B. and Alabi, R. O. (1994). Studies on traditional water purification using Moringa oleifera seeds. African Study Monographs, 15, pp. 135-142.

Price, F. A. and Yonge, D. R. (1995). Enhancing contaminant removal in stormwater detention basins by coagulation. Transportation Research Record, 1483, pp. 105-111.

Shan, T. C., Matar, M. A., Makky, E. A. and Ali, E. N. (2017). The use of Moringa oleifera seed as a natural coagulant for wastewater treatment and heavy metals removal. Applied Water Science, 7, pp. 1369-1376.

Shin, J. Y., Spinette, R. F. and O'Melia, C. R. (2008). Stoichiometry of coagulation revisited. Environmental science and technology, 42, pp. 2582-2589.

Song, H., Qin, T., Wang, J. and Wong, T. H. F. (2019) Characteristics of stormwater quality in Singapore Catchments in 9 different Types of Land Use. Water, 11, 1089, pp.1-10.

Sotheeswaran, S., Nand, V., Matakite, M. and Kanayathu, K. (2011) Moringa oleifera and other local seeds in water purification in developing countries. Research Journal of Chemistry and Environment, 15(2), pp. 135-138. 
USEPA (2008). NPDES Multi-Sector General Permit for Stormwater Discharges Associated with Industrial Activity (MSGP). U.S. Environmental Protection Agency, Washington D.C. 